\title{
Is the Primacy of EU Law Based on the Equality of the Member States? A Comment on the CJEU's Press Release Following the PSPP Judgment - ERRATUM
}

\section{J. Lindeboom}

https://doi.org/10.1017/glj.2020.52, Published by Cambridge University Press, 28 August 2020.

Keywords: primacy; sovereign equality; Kelsen; EU law; PSPP judgment; erratum

During typesetting of the original article, text was incorrectly removed from the penultimate paragraph and as such is not fully representative of the author. The publisher regrets this error and offers sincerest apologies to the author. The paragraph in full should read as follows:

"Accordingly, I read the press release as a creative attempt by the CJEU to maintain its stance while realizing that the old arguments have proved unconvincing for some of its interlocutors, to strengthen its voice by alluding to the Treaty text and the parlance of international law, and to remind us of Pandora's box that could be opened if neither the German government nor the BVerfG backs down. It remains to be seen whether the equality argument will also appear in the case law itself. In my view, this is better avoided: in substance the argument is weak and has no support in the case law. While I promised that I would not discuss the question whether issuing a press release was a sound choice, in one way it clearly is not: a succinct and weakly argued press release makes the latter vulnerable to obvious objections to its reasoning; not quite useful for a Court the quality of whose legal reasoning is currently contested, and is questioned more generally."

\section{Reference}

Lindeboom, J. (2020). Is the Primacy of EU Law Based on the Equality of the Member States? A Comment on the CJEU's Press Release Following the PSPP Judgment. German Law Journal, 21(5), 1032-1044. doi: 10.1017/glj.2020.52

\footnotetext{
Cite this article: Lindeboom J (2020). Is the Primacy of EU Law Based on the Equality of the Member States? A Comment on the CJEU's Press Release Following the PSPP Judgment - ERRATUM. German Law Journal 21, 1649. https://doi.org/10.1017/ glj.2020.88 